\title{
Kadar Fe(III) Pada Air Sumur Galian yang Dikonsumsi Masyarakat Menggunakan Spektrofotometer UV-VIS
}

\author{
Sriyana Ohi ${ }^{1}$, Sri Liani Minggu' ${ }^{1}$, Wiwin Rewini Kunusa ${ }^{2 *}$, Astin Lukum² \\ ${ }^{1}$ SMKN 1 Gorontalo, Jl. Ternate, Kota Gorontalo \\ ${ }^{2}$ Jurusan Kimia, Universitas Negeri Gorontalo, Jl. Prof. Dr. Ing. B.J Habibie, Bone Bolango, Gorontalo
}

\begin{abstract}
ABSTRAK
Dalam penelitian ini, dilakukan analisis kadar Fe(III) pada sampel air sumur galian yang dikonsumsi masyarakat sebanyak 10 sampel yang tersebar dibeberapa wilayah Kota Gorontalo. Sampel diasamkan dengan $0.3 \mathrm{~mL} \mathrm{HNO}_{3} 4 \mathrm{M}$ dan $0.5 \mathrm{~mL}$ KSCN 2M dan absorbansi diukur dalam Spektrometer UV-Visible. Nilai absorbansi dari hasil pengukuran larutan standar dengan deret konsentrasi $0.1,0.3,0.5,0.7$ dan $1 \mathrm{ppm}$ larutan induk Fe $100 \mathrm{ppm}$ diperoleh persamaan regresi linier $y=0.000 x+0.016$ dengan nilai regresi $\left(R^{2}\right)=$ 0.9860. ( $\left.\lambda_{\max }\right) 490 \mathrm{~nm}$ dengan nilai absorbansi $(\mathrm{A})$ tertinggi yakni 0.043 . Data ini digunakan untuk pengukuran sampel di lokasi I. Untuk Lokasi II, Nilai absorbansi dari hasil pengukuran larutan standar dengan deret konsentrasi $0.1,0.3,0.5,0.7$ dan 1 diperoleh persamaan regresi linier $y=0.036 x+0.006$ dengan nilai regresi $\left(R^{2}\right)$ 0.9800. $\left(\lambda_{\operatorname{Max}}\right) 510 \mathrm{~nm}$ dengan nilai absorbansi $(A)$ tertinggi yakni 0.025 . Hasil pengukuran sampel untuk Lokasi I yakni kode sampel $A=-0.1060, B=-0.0303, C=0.3780, D=0.1667$ dan $\mathrm{E}=0.3636$. Untuk Lokasi II yakni kode sampel $\mathrm{A}=0.175, \mathrm{~B}=0.050, \mathrm{C}=0.3780, \mathrm{D}=0.050$ dan $\mathrm{E}=0.675$. Disimpulkan bahwa, kandungan konsentrasi Fe di 5 lokasi ini masih dibawah NAB yakni $<1 \mathrm{mg} / \mathrm{L}$ karena konsentrasi Fe yang dianjurkan oleh WHO minimal adalah $1 \mathrm{mg} / \mathrm{L}$. Pada air tanah bervariasi mulai dari 0,01 $\mathrm{mg} / \mathrm{l}-25 \mathrm{mg} / \mathrm{l}$.
\end{abstract}

Kata Kunci : Besi; Sumur Galian; Spektrofotometer UV-VIS

\section{ABSTRACT}

In this study, an analysis of Fe (III) content conducted on 10 samples of dug well water consumed by the community was as many as 10 samples scattered in several areas of Gorontalo City. Samples were acidified with $0.3 \mathrm{~mL} 4 \mathrm{M} \mathrm{HNO3}$ and $0.5 \mathrm{~mL} \mathrm{KSCN} 2 \mathrm{M}$ and the absorbance was measured in a UV-Visible Spectrometer. Absorbance values from the results of standard measurements with a concentration series of $0.1,0.3,0.5,0.7$ and $1 \mathrm{ppm}$ obtained linear regression equation $y=0,000 x+0.016$ with a regression value $(R 2)=0,9860$. (גMax) $490 \mathrm{~nm}$ with the highest absorbance value $(A)$ is 0.043 . This data is used for sample measurement at location I. For Location II, the absorbance value from the results of standard measurements with concentrations of $0.1,0.3,0.5,0.7$ and 1 obtained a linear regression equation $y=0.036 x+0.006$ with regression value (R2) 0.9800. ( $(\mathrm{Max}) 510 \mathrm{~nm}$ with the highest absorbance value $(A)$ is 0.025 . Sample measurement results for My Location in sample code $A=-0.1060, B=-0.0303, C=0.3780, D=0.1667$ and $E=0.3636$. For Location II, the sample code $A=0.175, B=0.050, C=0.3780, D=0.050$ and $E=0.675$. It was concluded therefore, the concentration in Fe 5 of this location was still below the NAV of $<1 \mathrm{mg} / L$ because the minimum recommended Fe concentration by $W H O$ was $1 \mathrm{mg} / \mathrm{L}$. In ground water varies from $0.01 \mathrm{mg} / \mathrm{l}-25 \mathrm{mg} / \mathrm{l}$.

Keywords : Iron; well; UV-Vis Spectrometer

\section{Received: 17-22-2020, Accepted: 20-08-2020, Online: 25-08-2020}

\section{PENDAHULUAN}

Besi adalah logam kedua yang paling melimpah di kerak bumi. Besi terlarut dalam air, dapat berubah warna karena padatan tersuspensi yang mengandung mineral besi berwarna

\footnotetext{
*Corresponding author:

rewinikunusa2014@gmail.com
} 
kecoklatan. Besi (Fe) akan menimbulkan noda karat berwarna merah bata atau oranye di wastafel, toilet,

dan juga menyebabkan noda pakaian. Zat besi dapat mengendap dan akan bereaksi dengan kotoran-kotoran lainnya yang mengandung bakteri berbahaya yang sebagian besar ditemukan di sumur-sumur yang airnya belum diklorinasi. (U.S. EPA, 2017). Besi (Fe) merupakan unsur yang jarang ditemukan di alam, karena ion besi $\mathrm{Fe}^{2+}$ dan $\mathrm{Fe}^{3+}$ mudah bereaksi dengan oksigen dan belerang membentuk oksida, hidroksida, karbonat dan sulfida. Umumnya besi terlarut dalam bentuk oksida (Fawell et.al ,2017).

Air tanah pada umumnya mengandung zat besi $(\mathrm{Fe})$ dan mangan $(\mathrm{Mn})$ yang cukup besar. Adanya kandungan $\mathrm{Fe}$ dan $\mathrm{Mn}$ dalam air ditandai dengan adanya perubahan fisis, yaitu ditunjukkan dengan perubahan warna air menjadi kuning-coklat setelah terjadi oksidasi, yaitu beberapa saat kontak dengan udara. Selain itu, proses ini dapat mengganggu kesehatan juga menimbulkan bau yang kurang enak, serta menyebaban warna kuning pada dinding bak serta bercak-bercak kuning pada pakaian. Kadar besi ( $\mathrm{Fe}$ ) yang melebihi batas maksimal yang diperbolehkan pada air minum berdasarkan Permenkes No. 492/Menkes/PER/IV/2010 adalah 0.3 mg/l. Penelitian telah dilakukan pada 7 air sumur dalam 20 sampel di Kelurahan Gedung Johor, Medan secara spektofotometri serapan atom (SSA) konsentrasi besi (Fe) berkisar antara $0-0.963 \mathrm{mg} / \mathrm{l}$ (Siahaan, 2019).

Secara alami, zat besi terdapat dalam tumbuhan dan hewan. Hati, ginjal, ikan, dan sayuran hijau mengandung zat besi 20-150 mg/kg, sedangkan daging merah dan kuning telur mengandung 10$20 \mathrm{mg} / \mathrm{kg}$. Beras, buah-buahan dan sayuran memiliki kandungan zat besi yang rendah (1-10 mg/ $\mathrm{kg}$ ). Perkiraan total paparan Fe setiap hari dari asupan zat besi melalui air minum dan dalam makanan $\pm 10-14 \mathrm{mg} / \mathrm{L}$. Air minum yang mengandung $0,3 \mathrm{mg} / \mathrm{L}$ akan berkontribusi terhadap konsumsi air minum sekitar 0,6 mg setiap hari. Di daerah perkotaan, asupan zat besi dari udara $\pm 25 \mu \mathrm{g} / \mathrm{hari}$. Hasil analisis telah dilaporkan, di daerah terpencil kadar zat besi diudara $\pm 50-90$ $\mu \mathrm{g} / \mathrm{m} 3$ dan di lokasi perkotaan $\pm 1,3 \mu \mathrm{g} / \mathrm{m} 3$. Di sekitar pabrik besi dan baja konsentrasinya 12 $\mu \mathrm{g} / \mathrm{m} 3$. Konsentrasi besi di sungai $\pm 0,7 \mathrm{mg} /$ liter. Konsentrasi zat besi dalam air minum $<0,3 \mathrm{mg} / \mathrm{L}$. Secara anaerob besi dalam air tanah terdapat dalam bentuk besi(II) dimana konsentrasinya 0,5-10 $\mathrm{mg} / \mathrm{L}$. Akan tetapi biasanya dapat ditemukan konsentrasi hingga mencapai $50 \mathrm{mg} / \mathrm{L}$ ((Fawell, et al, 2003).

Salah satu metode yang mudah, efisien dan aman dikembangkan untuk menentukan zat besi dalam sampel air adalah Kit Uji Sel Spectroquant, yakni ion besi direduksi menjadi ion Fe(II) oleh asam askorbat menggunakan buffer tioklikolat. Fe(II) bereaksi dengan triazin membentuk kompleks ungu yang ditentukan secara fotometrik (Sreenivasareddy, 2017). Menentukan kadar $\mathrm{Fe}^{+2}$ di dalam sampel air metoda Spektrofotometri secara orto-penantrolin. Metoda Ortho Penantrolin Besi (III) direduksi menjadi $\mathrm{Fe}^{+2}$ dalam suasana asam dengan penambahan hidosilamin-klorida dan dengan adanya ortho penantrolin akan terbentukkomplek berwarna merah orange yang diukur absorbansinya pada panjanggelombang $510 \mathrm{~nm}$.

Spektrometer UV-Vis adalah instrumen yang digunakan untuk mengukur jumlah ultraviolet dan cahaya tampak yang diserap oleh sebuah larutan. Cahaya yang diserap menyebabkan elektron dipromosikan dari satu tingkat energi ke yang lain. Ion logam yang berbeda, memiliki pola penyerapan yang berbeda sehingga spektroskopi UV-VIS dapat digunakan untuk mengidentifikasi ion logam dalam larutan [Khopkar]. Penelitian pada 2 sampel air dilokasi berbeda menggunakan instrumen spektrometer UV-Visible pada $\lambda 565 \mathrm{~nm}$ menunjukkan kadar 0,45, 0,13, 3,84, 5,64, $6,72,5,78 \mathrm{ppm}$ untuk lokasi I dan $0,11,0,11,0,14,0,12$, dan $0,11 \mathrm{ppm}$ untuk lokasi II pada batas deteksi (LOD) adalah 0,10 ppm dan batas kuantifikasi (LOQ) adalah 1,0 ppm. (Sreenivasareddy, 2017). 


\section{METODDE PENELITIAN}

\section{Lokasi Pengambilan Sampel}

Sampel yang digunakan air sumur galian yang dikonsumsi masyarakat dan pengambilan sampel langsung dari air sumur. Preparasi sampel dilakukan saat akan melakukakn pengukuran. Sampel air sumur galian sebanyak 10 titik tersebar di dua titik lokasi diKota Gorontalo. Lokasi I dengan kode sampel A (Kelurahan Tanggikiki Kecamatan Sipatana), B (Kelurahan Talumolo Kecamatan Dumboraya), C (Desa Pilohayanga Kecamatan Telaga), D (Kelurahan Dulomo Kecamatan Kota Utara) dan E (Kelurahan Padebuolo, Kota Timur). Lokasi II dengan kode sampel A (Kompleks Pemandian Waterbum), B (Kelurahan Talumolo Kecamatan Dumboraya), C (Desa Pilohayanga Kecamatan Telaga), D (Kelurahan Dulomo Kecamatan Kota Utara) dan E (Kelurahan Padebuolo, Kota Timur).

\section{Pembuatan Larutan Induk Fe 100 ppm}

Sebanyak 0.215 gram $\left(\mathrm{NH}_{4}\right)_{2} \mathrm{Fe}\left(\mathrm{SO}_{4}\right)_{2} .12 \mathrm{H}_{2} \mathrm{O}$ dimasukkan dalam labu ukur $250 \mathrm{~mL}$ dan ditambahkan $0.3 \mathrm{~mL} \mathrm{HNO}_{3} 4 \mathrm{M}$ serta penambahan $0.5 \mathrm{~mL} \mathrm{KSCN} 2 \mathrm{M}$. Selanjutkan, dihomogenkan dan ditambahkan aquadest sampai tanda batas.

\section{Penentuan Parameter Analisis}

\section{Pembacaan Panjang Gelombang Maksimum}

Pengukuran panjang gelombang maksimum untuk kompleks $\left[\mathrm{Fe}(\mathrm{SCN})_{6}\right]^{3-}$ dilakukan dengan mengukur absorbansi larutan standar besi(III) 3 ppm yang telah ditambahkan dengan $0.3 \mathrm{~mL}$ $\mathrm{HNO}_{3} 4 \mathrm{M}$ dan $0.5 \mathrm{~mL} \mathrm{KSCN} 2 \mathrm{M}$ pada panjang gelombang $400-700 \mathrm{~nm}$.

\section{Pembuatan Kurva kalibrasi Fe(III) 0 ppm - 3 ppm}

Larutan $\mathrm{Fe}(\mathrm{III}) 100$ ppm dimasukkan sebanyak $0.5 \mathrm{~mL}(0.5 \mathrm{ppm}) ; 1 \mathrm{~mL}(1 \mathrm{ppm}) ; 1.5 \mathrm{~mL}$ (1.5 ppm); $2 \mathrm{~mL}(2 \mathrm{ppm}) ; 2.5 \mathrm{~mL}(2.5 \mathrm{ppm})$ dan $3 \mathrm{~mL}(3 \mathrm{ppm})$ pada labu ukur $10 \mathrm{~mL}$. Setiap konsentrasi ditambahkan $0.3 \mathrm{~mL} \mathrm{HNO}_{3} 4 \mathrm{M}$ dan $0.5 \mathrm{~mL}$ KSCN 2M kemudian dikocok sampai homogeny dan diencerkan sampai tanda batas. Selanjutnya diukur absorbansi pada panjang gelombang maksimum dan dibuat kurva yang merupakan hubungan antara absorbansi dan konsentrasi (Jeffery et al, 1989 ; Svehla, 1996).

\section{Penentuan $\mathrm{Fe}^{3+}$ Sampel Air Sumur dengan Spektrofotometer UV-VIS}

Sampel sebanyak $6 \mathrm{~mL}$ dimasukkan ke dalam labu ukur $10 \mathrm{~mL}$, kemudian ditambahkan dengan $0.3 \mathrm{~mL} \mathrm{HNO}_{3} 4 \mathrm{M}$ dan $0.5 \mathrm{~mL} \mathrm{KSCN} 2 \mathrm{M}$. Kemudian dikocok sampai homogeny dan diencerkan sampai tanda batas, Kemudian dibaca absorbansi pada panjang gelombang maksimum (Jeffery et al, 1989 ; Svehla, 1996).

\section{HASIL DAN ANALISIS}

Tahapan pelaksanaan analisis terdiri dari (1) pengukuran panjang gelombang maksimum dengan cara mengambil salah satu dari deretan larutan standar yang dibuat. Tujuannya untuk mencari panjang gelombang maksimun yang akan dilakukan untuk pembuatan kurva baku dan pengukuran konsentrasi sampel (b) pengukuran larutan standar (c) pengukuran larutan sampel. Dalam penelitian ini digunakan 10 titik lokasi untuk sampel air sumur yang tersebar dibeberapa kecamatan, Kota Gorontalo. Panjang gelombang $\left(\lambda_{\max }\right)$ yang digunakan untuk tahap pengukuran terdiri dari 2 yakni pada $\left(\lambda_{\text {Max }}\right) 490 \mathrm{~nm}$ dan $\left(\lambda_{\operatorname{Max}}\right) 510 \mathrm{~nm}$. 
Tabel.1 Pemilihan Panjang Gelombang Maksimum untuk Titik Lokasi I

\begin{tabular}{cccc} 
No & $\lambda_{\max }$ & Absorbansi $(\mathrm{A})$ & $\%$ Transmitansi $(\% \mathrm{~T})$ \\
\hline 1 & 450 & 0.028 & 93.8 \\
2 & 460 & 0.032 & 93.0 \\
3 & 470 & 0.037 & 92.0 \\
4 & 480 & 0.039 & 91.4 \\
5 & 490 & 0.043 & 91.0 \\
6 & 500 & 0.041 & 91.0 \\
7 & 510 & 0.039 & 91.6 \\
8 & 520 & 0.037 & 91.8 \\
9 & 530 & 0.038 & 91.6 \\
10 & 540 & 0.028 & 93.4 \\
11 & 550 & 0.021 & 95.2 \\
\hline
\end{tabular}

Berdasarkan data pada Tabel 1. didapatkan panjang gelombang maksimum $\left(\lambda_{\operatorname{Max}}\right) 490 \mathrm{~nm}$ dengan nilai absorbansi (A) tertinggi yakni 0.043 . Untuk analisis selanjutnya yakni pengukuran larutan standard dan sampel air sumur untuk Titik Lokasi I pada $\left(\boldsymbol{\lambda}_{\operatorname{Max}}\right) 490 \mathrm{~nm}$. Berikut hasil pengukuran larutan standar untuk Titik Lokasi I ( $\left.\lambda_{\text {Max }}\right) 490 \mathrm{~nm}$ ditunjukkan pada Tabel.2.

Tabel.2 Nilai Absorbansi Konsentrasi Larutan Standar Fe untuk Lokasi I

\begin{tabular}{cccc}
\hline No & Konsentrasi Larutan Standar $(\mathrm{ppm})$ & Absorbansi $(\mathrm{A})$ & $\%$ Transmitansi $(\% \mathrm{~T})$ \\
\hline 1 & 0.1 & 0.028 & 93.8 \\
2 & 0.3 & 0.034 & 92.6 \\
3 & 0.5 & 0.042 & 91.0 \\
4 & 0.7 & 0.064 & 86.4 \\
5 & 1 & 0.085 & 82.2 \\
\hline
\end{tabular}

Berdasarkan data pada Tabel 2. Larutan standar atau larutan baku adalah suatu larutan yang mengandung konsentrasi yang diketahui secara tepat dari unsur atau zat. Nilai absorbansi dari hasil pengukuran larutan standar $\mathrm{Fe}$ dari $\left(\mathrm{NH}_{4}\right)_{2} \mathrm{Fe}\left(\mathrm{SO}_{4}\right)_{2} .12 \mathrm{H}_{2} \mathrm{O}$ dengan deret konsentrasi $0.1,0.3,0.5,0.7$ dan $1 \mathrm{ppm}$ larutan induk $\mathrm{Fe} 100 \mathrm{ppm}$ yang ditambahkan $\mathrm{HNO}_{3} 4 \mathrm{M}$ dan $0.5 \mathrm{gr} \mathrm{KSCN} 2 \mathrm{M}$. Nilai absorbansi larutan standar dibuat kurva kalibrasi/kurva standar yang menunjukkan hubungan antara konsentrasi larutan (sumbu-x) dengan absorbansi larutan (sumbuy). Berikut kurva kalibrasi untuk Titik Lokasi I $\left(\lambda_{\max }\right) 490 \mathrm{~nm}$ ditunjukkan pada Gambar.1

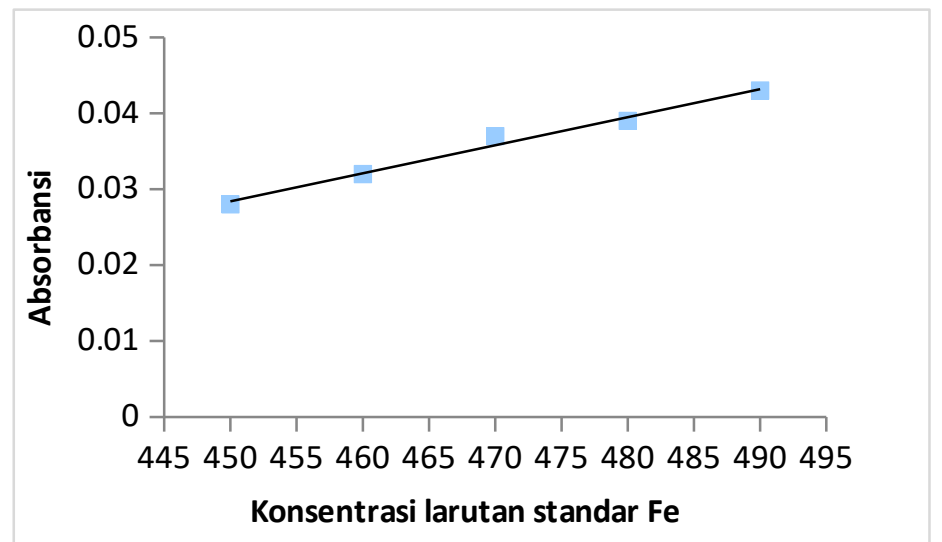

Gambar.1 Kurva Kalibrasi Fe untuk Titik Lokasi II $\left(\lambda_{\operatorname{Max}}\right) 490 \mathrm{~nm}$ 
Kurva kalibrasi merupakan grafik yang membentuk garis lurus (linier) yang menyatakan hubungan antara kadar larutan kerja termasuk blanko dengan respon yang proporsional dari instrument yang memenuhi persamaan 1.

$$
y=b x+a
$$

dimana : $\mathrm{a}=$ Intersep (Intercept), $\mathrm{b}=$ Kemiringan (slope), $\mathrm{x}=$ kadar analit dan $\mathrm{y}=$ respon instrument.

Berdasarkan Gambar 1, nilai absorbansi dari hasil pengukuran larutan standar dengan deret konsentrasi $0.1,0.3,0.5,0.7$ dan $1 \mathrm{ppm}$ larutan induk Fe $100 \mathrm{ppm}$ diperoleh persamaan regresi linier $y=0.000 x+0.016$ dengan nilai regresi $\left(R^{2}\right)=0.9860$. Berikut data hasil pengukuran larutan sampel untuk Titik Lokasi I $\left(\lambda_{\text {Max }}\right) 490 \mathrm{~nm}$ ditunjukkan pada Tabel.3

Tabel.3. Nilai Absorbansi Sampel Air Sumur untuk Lokasi I

\begin{tabular}{clccc}
\hline No & \multicolumn{1}{c}{ Kode Sampel dan Lokasi } & Abs (A) & $\%$ T & ppm \\
\hline 1 & A (Kelurahan Tanggikiki, Sipatana) & 0.009 & 98.0 & -0.1060 \\
2 & B (Kelurahan Talumolo, & 0.014 & 97.0 & -0.0303 \\
3 & Dumboraya) & 0.041 & 91.0 & 0.3780 \\
4 & D (Kesa Pilohayanga, Talaga) & 0.027 & 94.2 & 0.1667 \\
5 & E (Kelurahan Dulomo, Kota Utara) & 0.040 & 91.0 & 0.3636 \\
\hline
\end{tabular}

Berdasarkan data pada Tabel 2 sampel A-E memiliki konsentrasi $\mathrm{Fe}(\mathrm{III})<0,05-0,1 \mathrm{mg} / \mathrm{L}$. Kekeruhan air akan terjadi jika konsentrasi $\mathrm{Fe}(\mathrm{III})$ menjadi > 0,05-0,1 $\mathrm{mg} / \mathrm{L}$ bahkan pada konsentrasi $\mathrm{Fe}(\mathrm{III})>0,3 \mathrm{mg} / \mathrm{L}$ sudah terjadi perubahan warna cucian. Pada sampel $\mathrm{C}$ dan $\mathrm{E}$ konsentrasi $\mathrm{Fe}$ (III) $0.3780 \mathrm{ppm}$ dan $0.3636 \mathrm{ppm}$ lebih tinggi dibandingkan lokasi lainnya sementara untuk lokasi D konsentrasi Fe(III) 0.1667 ppm. Bahkan untuk lokasi A dan B konsentrasi $\mathrm{Fe}$ (III) tidak terdeteksi (ND). Hasil analisis disetiap titik lokasi menunjukkan konsentrasi Fe(III) pada air sumur masih sangat rendah yakni $<0,05-0,1 \mathrm{mg} / \mathrm{L}$. Kemungkinan untuk terjadinya kekeruhan bahkan mempengaruhi perubahan warna cucian tidak perlu dikhawatirkan oleh masyarakat dibeberapa lokasi ini. Dalam air minum, garam Fe(II) tidak stabil dan diendapkan sebagai $\mathrm{Fe}_{3}(\mathrm{OH})_{2}$ yang tidak larut sebagai sedimen berkarat.

Tabel.4 Pemilihan Panjang Gelombang Maksimum untuk Titik Lokasi II

\begin{tabular}{cccc}
\hline No & $\lambda_{\max }$ & Absorbansi (A) & $\%$ Transmitansi $(\% \mathrm{~T})$ \\
\hline 1 & 450 & 0.01 & 98 \\
2 & 460 & 0.01 & 97 \\
3 & 470 & 0.015 & 96 \\
4 & 480 & 0.02 & 95 \\
5 & 490 & 0.02 & 95 \\
6 & 500 & 0.02 & 94 \\
7 & 510 & 0.025 & 94 \\
8 & 520 & 0.02 & 95 \\
9 & 530 & 0.02 & 95 \\
10 & 540 & 0.001 & 98 \\
11 & 550 & 0.015 & 97 \\
\hline
\end{tabular}

Ketika air dipompa langsung dari sumur kemungkinan mengandung $\mathrm{Fe}(\mathrm{II})$ pada konsentrasi rendah hingga beberapa miligram per liter tanpa warna atau kekeruhan. Hasil pengukuran 
pemilihan panjang gelombang maksimum untuk pengukuran sampel air sumur di titik lokasi II ditunjukkan pada Tabel.4

Berdasarkan data pada Tabel 4, Pemilihan panjang gelombang maksimum dilakukan dengan cara mengukur salah satu konsentrasi larutan standard an didapatkan panjang gelombang maksimum $\left(\lambda_{\operatorname{Max}}\right) 510 \mathrm{~nm}$ dengan nilai absorbansi $(A)$ tertinggi yakni 0.025 . Untuk analisis selanjutnya yakni pengukuran larutan standard dan sampel air sumur untuk Titik Lokasi II pada $\left(\lambda_{\operatorname{Max}}\right) 510 \mathrm{~nm}$. Hasil pengukuran larutan standar untuk pengukuran sampel diLokasi II ( $\left.\lambda_{\operatorname{Max}}\right) 510$ nm ditunjukkan pada Tabel.5.

Tabel.5 Nilai Absorbansi Konsentrasi Larutan Standar Fe untuk Lokasi II

\begin{tabular}{cccc}
\hline No & $\begin{array}{c}\text { Konsentrasi Larutan } \\
\text { Standar (ppm) }\end{array}$ & Absorbansi (A) & $\%$ Transmitansi (\%T) \\
\hline 1 & 0.1 & 0.01 & 98 \\
2 & 0.3 & 0.02 & 95 \\
3 & 0.5 & 0.025 & 94 \\
4 & 0.7 & 0.03 & 94 \\
5 & 1 & 0.045 & 90 \\
\hline
\end{tabular}

Berdasarkan data pada Tabel 5. Nilai absorbansi dari hasil pengukuran larutan standar sebagai data kurva kalibrasi yakni grafik yang membentuk garis lurus (linier) yang menyatakan hubungan antara kadar larutan kerja termasuk blanko dengan respon yang proporsional dari instrument yang memenuhi persamaan regresi linier sebagai berikut : $y=b x+a$ dimana : $a=$ Intersep (Intercept), $\mathrm{b}=$ Kemiringan (slope), $\mathrm{x}=$ kadar analit dan $\mathrm{y}=$ respon instrument. Berdasarkan Gambar 2. Nilai absorbansi dari hasil pengukuran larutan standar dengan deret konsentrasi $0.1,0.3,0.5,0.7$ dan $1 \mathrm{ppm}$ larutan induk Fe $100 \mathrm{ppm}$ diperoleh persamaan regresi linier $y=0.036 x+0.006$ dengan nilai regresi $\left(R^{2}\right)=0.9800$.

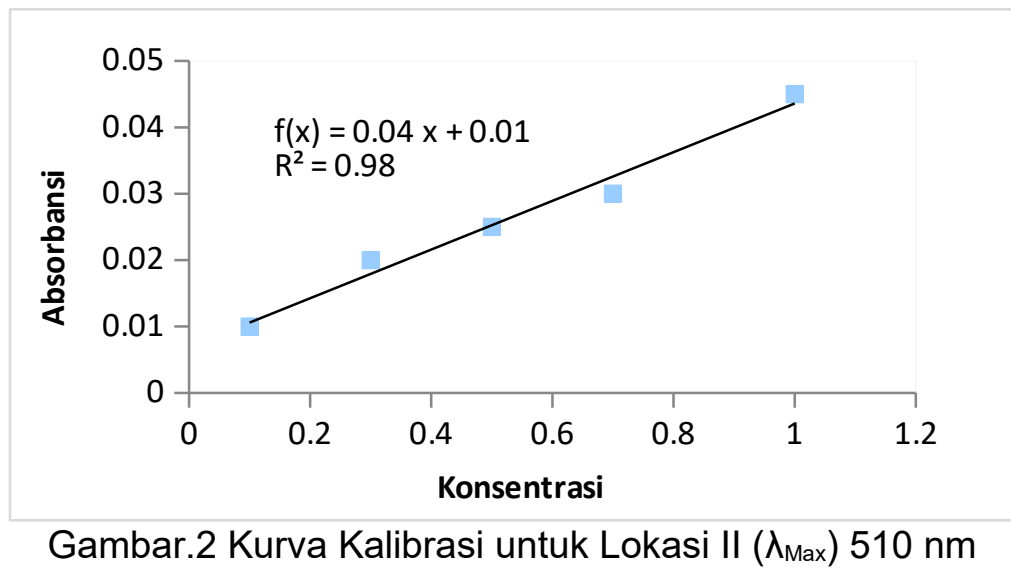

Hasil pengukuran larutan sampel air sumur untuk Lokasi II pada ( $\left.\lambda_{\max }\right) 510 \mathrm{~nm}$ dengan kode sampel A, B, C, D dan E ditunjukkan pada Tabel.6.

Tabel.6. Nilai Absorbansi Sampel Air Sumur untuk Lokasi II $\lambda_{\max } 510 \mathrm{~nm}$

\begin{tabular}{ccccc}
\hline No & \multicolumn{1}{c}{ Kode Sampel dan Lokasi } & Abs (A) & $\%$ T & ppm \\
\hline 1 & A (Kompleks pemandian Waterbum) & 0.010 & 98.0 & 0.175 \\
2 & B (Kelurahan Talumolo, Dumboraya) & 0.014 & 97.0 & 0.050 \\
3 & C (Kelurahan Bugis, Kota Timur) & 0.012 & 91.0 & 0.225 \\
4 & D (Kelurahan Dulomo, Kota Utara) & 0.027 & 94.2 & 0.050 \\
5 & E (Kelurahan Padebuolo, Kota Timur) & 0.003 & 91.0 & 0.675 \\
\hline
\end{tabular}


Berdasarkan data pada Tabel. 6 dengan menggunakan persamaan regresi linier $y=b x+a$ maka konsentrasi $\mathrm{Fe}(\mathrm{III})$ pada beberapa lokasi dapat diketahui. Sampel E memiliki konsentrasi $\mathrm{Fe}(\mathrm{III})$ tertinggi yakni $0.675 \mathrm{ppm}$. Sampel C $0.225 \mathrm{ppm}$ dan sampel A $0.175 \mathrm{ppm}$. Untuk lokasi B dan $D$ memiliki konsentrasi Fe(III) yang sama yakni 0.050 ppm. Kandungan konsentrasi Fe di 5 lokasi ini masih dibawah NAB yakni $<1 \mathrm{mg} / \mathrm{L}$ karena konsentrasi Fe yang dianjurkan oleh WHO minimal adalah $1 \mathrm{mg} / \mathrm{L}$. Pada air tanah bervariasi mulai dari $0,01 \mathrm{mg} / \mathrm{l}-25 \mathrm{mg} / \mathrm{l}$. Hasil analisis [Asmaningrum et al, 2016] kadar Fe untuk air minum diproduksi dan didistribusikan oleh Depot Air Minum Isi Ulang (DAMIU, Merauke) $<1 \mathrm{mg} / \mathrm{L}$ yakni $0.05-0.08 \mathrm{ppm}$. Pada air permukaan jarang ditemui kadar Fe melebihi $1 \mathrm{mg} / \mathrm{l}$, tetapi di dalam air tanah kadar $\mathrm{Fe}$ dapat jauh lebih tinggi (Manahan, 1999). Konsentrasi Fe yang tinggi dapat dirasakan dan dapat menodai kain serta perkakas dapur. Pada air yang tidak mengandung oksigen seperti air tanah, besi berada sebagai $\mathrm{Fe}^{2+}$ yang cukup tinggi, sedangkan pada air sungai yang mengalir dan terjadi aerasi, $\mathrm{Fe}^{2+}$ teroksidasi menjadi $\mathrm{Fe}(\mathrm{OH})_{3}$, dimana $\mathrm{Fe}(\mathrm{OH})_{3}$ ini sulit larut pada $\mathrm{pH} 6$ sampai 8.

\section{SIMPULAN}

Hasil pengukuran sampel untuk Lokasi I yakni kode sampel $A=-0.1060, B=-0.0303, C=$ $0.3780, D=0.1667$ dan $E=0.3636$. Untuk Lokasi II yakni kode sampel $A=0.175, B=0.050, C=$ $0.3780, \mathrm{D}=0.050$ dan $\mathrm{E}=0.675$. Disimpulkan bahwa, kandungan konsentrasi Fe di 5 lokasi ini masih dibawah NAB yakni $<1 \mathrm{mg} / \mathrm{L}$ karena konsentrasi Fe yang dianjurkan oleh WHO maksimall adalah $1 \mathrm{mg} / \mathrm{L}$. Pada air tanah bervariasi mulai dari $0,01 \mathrm{mg} / \mathrm{l}-25 \mathrm{mg} / \mathrm{l}$. Dengan demikian, air sumur dapat dikonsumsi.

\section{DAFTAR PUSTAKA}

WHO. Iron in Drinking-water. Background document for development of WHO Guidelines for Drinking-water Quality Originally published in Guidelines for drinking-water quality, 2nd ed. Vol. 2. Health criteria and other supporting information. World Health Organization, Geneva, 1996. National Research Council. Iron. Baltimore, MD, University Park Press, 1979.

National Research Council. Iron. Baltimore, MD, University Park Press, 1979

Sreenivasareddy, Annem. 2017. Determination of Iron Content in Water. For the Degree of Masters of Science, With a Major in Analytical Chemistry Governors State University University Park, IL 60484

U.S. EPA. Secondary Drinking Water Standards: Guidance for Nuisance Chemicals, website https://www.epa.gov/dwstandardsregulations/secondary-drinking-water-standardsguidance-nuisance-chemicals (accessed October 7, 2017).

Fawell, J.K; Land.U; Mintz, B. Iron in Drinking water. Back ground document for development of WHO Guidelines for Drinking Water Quality. (online); Geneva, 2003. http://www.who.int/water_sanitation_health/dwq/chemicals/iron.pdf (accessed on October 9 2017)

Khopkar, S. (2003). Konsep Dasar Kimia Analitik. Jakarta: UI Press.

Henie Poerwandar Asmaningrum, Yenni Pintauli Pasaribu, 2016. Penentuan Kadar Besi(Fe) dan Kesadahan pada Air Minum Isi Ulang DI DISTRIK MERAUKE. Jurusan Pendidikan Kimia FKIP_Universitas Musamus 
Maniur Arianto Siahaan, 2019. Analisis Kadar Besi (Fe) pada Air Sumur Gali Penduduk Wilayah Kompleks Rahayu Kelurahan Mabar, Medan. Jurnal Kimia Saintek dan Pendidikan Volume III, Nomor 1, Tahun 2019, Hal 19-22 e-ISSN 2615-3378 